\title{
Humanistyka cyfrowa: problemy definiowania pojęcia ${ }^{1}$
}

\author{
Joanna Ucińska \\ Kolegium Międzywydziałowych Indywidualnych Studiów Humanistycznych \\ Uniwersytet Warszawski
}

\begin{abstract}
Abstrakt
Cel/Teza: Celem artykułu jest próba wskazania kluczowych cech pojęcia humanistyki cyfrowej oraz zrozumienie, co naprawdę jest rozumiane przez to pojęcie.

Koncepcja/Metody badań: Autorka analizuje najbardziej charakterystyczne cechy pojawiające się $\mathrm{w}$ definicjach digital humanities $\mathrm{w}$ naukowej literaturze anglojęzycznej oraz zestawia je z cechami najczęściej pojawiającymi się w polskich definicjach pojęcia humanistyka cyfrowa.

Wyniki i wnioski: Wynik badań jest negatywny - nie jest możliwe stworzenie jednego zestawu cech HC, ale możliwe jest wskazanie takich właściwości humanistyki cyfrowej, co do których większość badaczy jest zgodna.

Oryginalność/Wartość poznawcza: Największą wartość poznawczą pracy stanowi fakt, że jest to pierwsza systematyczna analiza oraz zestawienie definicji polskich i anglojęzycznych humanistyki cyfrowej.
\end{abstract}

\section{Słowa kluczowe}

Analiza. Definicje. Cyfrowa. Humanistyka. Humanistyka cyfrowa.

Otrzymany: 10 maja 2017. Zrecenzowany: 19 lipca 2017. Zaakceptowany: 4 września 2017.

\section{Wstęp}

W drugim numerze Zagadnień Informacji Naukowej z 2016 r. ukazał się artykuł Marii Przastek-Samokowej, w którym autorka kreśli obraz pojęcia humanistyka cyfrowa (HC) w polskim piśmiennictwie naukowym (rozumianym nietradycyjnie - badaczka analizuje nie tylko artykuły naukowe, ale i teksty popularnonaukowe, zaproszenia na konferencje lub wykłady specjalne, strony internetowe i wpisy na blogach) oraz przedstawia zarys pola semantycznego HC (Przastek-Samokowa, 2016). Przedstawiona w tym artykule klasyfikacja w trafny sposób podsumowuje zróżnicowane sposoby postrzegania humanistyki cyfrowej przez polskich naukowców, jednak nie wyczerpuje spektrum problemów ani nie zgłębia podejścia normatywnego ukazanego w polskich tekstach. Poszukując w swoich badaniach uniwersalnych cech definicji humanistyki cyfrowej, na podstawie analizy literatury zagranicznej oraz polskiej wyprowadziłam nieco inne wnioski niż konkluzje Marii Przastek-Samokowej,

1 Artykuł powstał na podstawie pracy magisterskiej autorki pt. Humanistyka cyfrowa w Polsce. Kierunki badań, ośrodki, projekty, napisanej pod kierunkiem prof. dr hab. Barbary Sosińskiej-Kalaty na Wydziale Dziennikarstwa, Informacji i Bibliologii Uniwersytetu Warszawskiego. 
dlatego też ze względu na złożoność i wielostronność zagadnienia warto ponownie podjąć temat rozumienia pojęcia/zakresu znaczeniowego określenia humanistyka cyfrowa.

Termin humanistyka cyfrowa nie został jeszcze jednoznacznie zdefiniowany, mimo że określa się w ten sposób stale rozszerzające się pole badań. Co więcej, sama dyscyplina również nie ma wyraźnie oznaczonych granic ani jasno zarysowanej metodologii; jak zauważa Patrik Svensson w artykule The digital humanities as humanities project, charakteryzują ją za to nieustannie toczące się negocjacje oraz ścieranie się tradycji epistemicznych i radykalnie odmiennych wizji rozwoju (Svensson, 2012, 42). Do takiego stanu rzeczy w największej mierze doprowadziła zmiana terminologiczna, która nastąpiła w latach 2004-2006 i na którą kluczowy wpływ miały trzy wydarzenia: publikacja książki $A$ Companion to Digital Humanities (2004)2 $)^{2}$ założenie organizacji parasolowej dla branżowych stowarzyszeń naukowych Alliance of Digital Humanities Organization (ADHO) oraz inauguracja Digital Humanities Initiative przez National Endowment for the Humanities, niezależną agencję federalną rządu amerykańskiego (Kirschenbaum, 2010).

Pojęcie digital humanities było używane w literaturze naukowej przed 2004 r., ale badania dziś określane mianem humanistyki cyfrowej zaliczano do dziedziny humanities computing, która ówcześnie miała już ugruntowaną tradycję, sięgającą lat 50. XX w. (Vanhoutte, 2013). Niemniej jednak przywołana wyżej publikacja, wydana w 2004 r. i zredagowana przez Susan Schreibman, Raya Siemensa oraz Johna Unswortha, doprowadziła do zmiany postrzegania pola badawczego i przyczyniła się do ustanowienia digital humanities jako nazwy dla całej dyscypliny (Vanhoutte, 2013). Jak wspomina w swoim eseju Matthew Kirschenbaum, wybór tytułu dla tego zbioru tekstów był wynikiem negocjacji między redaktorami a działem marketingu, który proponował nazwę A companion to digitized humanities; John Unsworth zaproponował $A$ companion to digital humanities, aby nie ograniczać pola skojarzeń tylko do digitalizacji (Kirschenbaum, 2010, 57).

Status nowej nazwy został ugruntowany rok później, gdy w wyniku połączenia Association for Computers in the Humanities i Association for Literary and Linguistic Computing w 2005 r. powstało Alliance of Digital Humanities Organization (ADHO) - grupa patronacka dla organizacji i stowarzyszeń zajmujących się humanistyką cyfrową. Ostatnim z wymienionych wydarzeń zasadniczych dla ukonstytuowania się określenia digital humanities jako nazwy dziedziny było powołanie w 2006 r. Digital Humanities Initiative - inicjatywy National Endowment for the Humanities (NEH), jednego z najważniejszych publicznych podmiotów w Stanach Zjednoczonych udzielających dofinansowania w dziedzinie nauk humanistycznych, która miała na celu przyznawanie grantów na projekty z zakresu humanistyki cyfrowej. Dwa lata później inicjatywa została przekształcona w Office of Digital Humanities - biuro dysponujące stałym budżetem, co podniosło prestiż nowopowstałej dyscypliny (Kirschenbaum, 2010).

Zmiana nazwy zapoczątkowała serię dyskusji i prób zdefiniowania czym jest humanistyka cyfrowa; pojawiły się również inne, choć o wiele mniej liczne refleksje, dotyczące statusu humanistyki cyfrowej jako dziedziny odrębnej od humanities computing. Patrik Svensson w pracy Humanities computing as digital humanities udowadnia, że transformacja, która się dokonała, ma następstwa nie tylko w dyskursie, ale i na płaszczyznach dyscyplinarnej,

${ }^{2}$ W styczniu 2016 r. wydawnictwo Wiley opublikowało drugie wydanie tego opracowania pt. A New Companion to Digital Humanities. 
instytucjonalnej oraz społecznej (w odniesieniu do społeczności akademickiej) (Svensson, 2013, 160). Jego zdaniem nie powinno się utożsamiać tych dwóch pól badawczych: pojęcie digital humanities ma szerszy zakres i zawiera w sobie humanities computing (Svensson, 2013, 175). Sytuację ponadto komplikuje fakt, że w literaturze przedmiotu wyróżnia się dwie fale humanistyki cyfrowej. The Digital Humanities Manifesto 2.0 zwraca uwagę na ilościowy charakter pierwszej z nich i dążenie do automatyzacji pracy z tekstem; drugą zaś określa jako jakościową, empiryczną, generatywną oraz skoncentrowaną na interpretacji (DH Manifesto 2.0, 2009). David M. Berry wyodrębnia także trzecią falę humanistyki cyfrowej, skupioną na kodzie komputerowym uwikłanym we wszystkie aspekty kultury i pamięci. Według badacza odmiana ta prowadzi do wskazywania przez nowoczesne technologie nieprawidłowości pojawiających się w badaniach humanistycznych oraz zakwestionowania przyjętych założeń nie wprost, takich jak uznane kanony czy humanizm liberalny (Berry, 2012). Teoria Berry'ego nie jest szeroko przyjmowana, jednak warto ją odnotować w kontekście problemów z określeniem dyscypliny.

Liczba definicji pojęcia digital humanities nie została ustalona. Temat nakreślenia ram dyscypliny i opisania metodologii był podnoszony wielokrotnie, zarówno jako główny problem tekstu, jak i jedynie element jego ramy teoretycznej, o czym wspomina Matthew Kirschenbaum w artykule What Is Digital Humanities and What's It Doing in English Departments? (Kirschenbaum, 2010). Co więcej, proces definiowania nie jest ograniczony do tradycyjnego medium, rozumianego w tym przypadku jako publikacja naukowa - ma miejsce również w internetowych kanałach komunikacji naukowej. Od 2009 r. uczestnicy realizowanego na łamach mediów społecznościowych projektu Day of Digital Humanities są zapraszani nie tylko do blogowania, ale i do odpowiadania na pytanie „What is Digital Humanities?" (Terras et al., 2013b, 279). Jason Heppler zarchiwizował 817 takich wypowiedzi z lat 2009-2014, które następnie umieścił w bazie danych połączonej ze stroną internetową http://whatisdigitalhumanities.com, na której za każdym razem po odświeżeniu wyświetlana jest inna definicja. Na podstawie odpowiedzi zebranych podczas Day of DH w 2011 r. Fred Gibbs zaproponował własną kategoryzację definicji humanistyki cyfrowej, w której najliczniejsze grupy stanowią „variation on «the application of technology to humanities work»”, „working with digital media or a digital environment” oraz „minimize the difference between DH and humanities" (Gibbs, 2013, 290).

Sytuacja ta stała się na tyle symptomatyczna, że artykuły, w których próbuje się zdefiniować pojęcie digital humanities są określane jako genre pieces (Kirschenbaum, 2010). Systematyczne podejście do problemu zostało zaprezentowane w książce Defining Digital Humanities z 2013 r. - publikacja przedstawia wybór 21 artykułów naukowych i wpisów z blogów podejmujących tematykę definiowania humanistyki cyfrowej. Celem redaktorów nie była jednak próba normatywnego ujęcia zjawiska, ale zaprezentowanie przekroju dyskusji wyznaczających granice postrzegania dyscypliny (Terras et al., 2013a). Podobne ujęcie przedstawione zostało w Debates in the Digital Humanities, książce wydanej rok wcześniej, w której problemowi definicji poświęcono jedną z sześciu części, a zawarte w niej artykuły także miały przedstawić różne stanowiska w debatach toczących się wokół definiowania humanistyki cyfrowej. 


\section{Próba oceny popularności definicji humanistyki cyfrowej najszerzej przyjmowanych w literaturze anglojęzycznej}

\subsection{Metodologia}

Ze względu na brak zgody co do tego w jaki sposób powinna być rozumiana humanistyka cyfrowa oraz w celu ustalenia co w dyskursie naukowym faktycznie oznacza digital humanities zdecydowałam się przeanalizować cztery definicje najszerzej przyjmowane w literaturze anglojęzycznej. Za wskaźnik popularności oraz poziomu akceptacji w obrębie dyscypliny uznałam liczbę cytowań artykułu, w którym została zawarta dana definicja - nawet jeśli niektórzy z cytujących ją autorów odnieśli się do niej polemicznie, szeroki odzew świadczy o wpływie, który wywarła. Liczba cytowań została ustalona na podstawie bazy danych wyszukiwarki Google Scholar ze względu na fakt, że baza Scopus nie podaje ich wiarygodnej liczby przy tekstach naukowych z dziedziny humanistyki cyfrowej - m.in. artykuł What is Digital Humanities and What's It Doing in English Departments według bazy Scopus był cytowany 2 razy, podczas gdy w Google Scholar widnieje liczba 179 odwołań; analogiczny problem powtarzał się w przypadku pozostałych anglojęzycznych tekstów naukowych, które cytuję. Przyjęłam, że minimalna liczba cytowań, niezbędna do określenia oddziaływania danej publikacji, wynosi 50 - wydaje się, że poniżej tej granicy trudno mówić o szerokim oddźwięku artykułu. Ponieważ jedynie trzy publikacje zawierające definicję humanistyki cyfrowej i zaindeksowane przez Google Scholar spełniły to kryterium, pod uwagę wzięłam także definicję podaną przez czasopismo Digital Humanities Quarterly. W analizie nie zostały uwzględnione natomiast artykuły z blogów - chociaż niektóre z nich spotkały się z głośną reakcją środowiska cyfrowych humanistów, to jednak nie istnieją odpowiednie narzędzia, które pozwoliłyby ocenić ten wpływ.

\subsection{Definicja z monografii Digital_Humanities}

Najczęściej cytowana definicja humanistyki cyfrowej pochodzi z książki autorstwa Anne Burdick, Johanny Drucker, Petera Lunenfelda, Todda Presnera oraz Jeffreya Schnappa Digital_Humanities, która ukazała się w 2012 r. nakładem MIT Press. Pozycja ta była cytowana 251 razy; definicja digital humanities została umieszczona w ostatnim rozdziale książki, stanowiącym krótki przewodnik po humanistyce cyfrowej. Zdaniem jej autorów,

Digital Humanities refers to new modes of scholarship and institutional units for collaborative, transdisciplinary, and computationally engaged research, teaching, and publication.

Digital Humanities is less a unified field than an array of convergent practices that explore a universe in which print is no longer the primary medium in which knowledge is produced and disseminated (Burdick et al., 2012, 122).

Taką propozycję eksplikacji omawianego określenia można zaliczyć do definicji kontekstowych; ponadto zauważalny jest w niej podział na dwa człony, z których każdy mógłby stanowić oddzielną definicję. Niemniej możliwa jest również spójna interpretacja - części nie wykluczają się wzajemnie.

Pierwszy fragment dotyczy punktu odniesienia humanistyki cyfrowej, tutaj rozumianego jako nowe formy prowadzenia studiów oraz nowe typy jednostek akademickich (i nie tylko), przeznaczonych do prowadzenia interdyscyplinarnych badań we współpracy 
z innymi instytucjami, z wykorzystaniem metod obliczeniowych (komputerowych) oraz do nauczania i działalności publikacyjnej. Ogólne wskazanie na nowatorstwo, sugerowane przez zwrot new modes of, wydaje się uzasadnione w sytuacji, gdy dyscyplina znajduje się w fazie gwałtownych przemian; ciekawość mogłoby wzbudzić natomiast bardzo konkretne określenie charakteru badań realizowanych w jednostkach badawczych zajmujących się humanistyką cyfrową, który ma być interdyscyplinarny, wykorzystywać nowe technologie i opierać się na współpracy. Być może tak precyzyjne wskazanie podyktowane było koniecznością ustanowienia standardów, które powinny obowiązywać w tej konkretnej działalności naukowej i które w tradycyjnej humanistyce nie są rozpowszechnione. Ostatni element pierwszej części definicji, odwołujący się do działalności edukacyjnej i wydawniczej świadczy o świadomości tego, że dla rozwoju tego nowego modelu humanistyki konieczne jest wychowywanie następnych pokoleń humanistów cyfrowych oraz popularyzowanie wyników prowadzonych badań.

W drugim członie następuje doprecyzowanie pojęcia humanistyki cyfrowej, którą autorzy Digital_Humanities definiują jako gamę zbieżnych praktyk umożliwiających badanie uniwersum, w którym druk nie jest już głównym medium tworzenia i upowszechniania wiedzy. Ten fragment jest dosłownym zapożyczeniem ze wspominanego wyżej The Digital Humanities Manifesto 2.0 z 2009 roku i w oryginale brzmi w następujący sposób:

Digital Humanities is not a unified field but an array of convergent practices that explore a universe in which: a) print is no longer the exclusive or the normative medium in which knowledge is produced and/or disseminated; instead, print finds itself absorbed into new, multimedia configurations; and b) digital tools, techniques, and media have altered the production and dissemination of knowledge in the arts, human and social sciences (DH Manifesto 2.0, 2009, akapit 9).

Zacytowanie tego passusu nie jest zaskakujące - część autorów The Digital Humanities Manifesto 2.0 jest związana z Uniwersytetem Kalifornijskim, podobnie jak niektórzy autorzy omawianej książki, istnieje więc pewne prawdopodobieństwo, że któryś z nich przyczynił się do powstania manifestu. Definicja z Digital_Humanities jest okrojona z jednego fragmentu względem pierwowzoru, ponadto ma złagodzoną formę, o czym świadczy zastosowanie innych spójników - w oryginale jest to „[Digital Humanities] is not...but” (Burdick et al., 2012, 122), a w zapożyczeniu „[Digital Humanities] is less...than” (DH Manifesto 2.0, 2009, akapit 9). Mimo zauważalnych zmian, w obu przypadkach ten pierwszy człon jest ważny wskazuje na to, czym według autorów nie jest humanistyka cyfrowa, mianowicie nie jest jednolitą dziedziną naukową.

Główną konsekwencją takiego rozróżnienia jest zaprzeczenie statusu humanistyki cyfrowej jako nauki tradycyjnej, z czym wiąże się otwarty charakter środowiska cyfrowych humanistów - mogą nimi być również naukowcy, którzy dotychczas nie afiliowali się w ten sposób; w tym sensie zniesiony zostaje warunek instytucjonalizacji, który w naukach tradycyjnych uznaje się za jedno z tzw. zewnętrznych kryteriów oceny stopnia autonomizacji dyscypliny naukowej (por. Kamiński, 1998, 254-257). Mogłoby się wydawać, że drugi fragment definicji staje przez to w sprzeczności z pierwszym, w którym wspomina się o nowych instytucjach, ale prawdopodobnie należy rozumieć tę myśl szerzej: o ile nowe formy prowadzenia studiów mogą wymagać tworzenia nowych jednostek akademickich, o tyle instytucjonalizacja i określanie humanistyki cyfrowej mianem dziedziny czy dyscypliny naukowej może prowadzić do zamknięcia jej na międzyobszarowość, nowości i prowadzić do skostnienia, co byłoby zaprzeczeniem tego, w jaki sposób autorzy Digital_Humanities ją pojmują. 
W kontekście instytucjonalizacji oraz wyznaczania granic dziedzin naukowych warto zwrócić uwagę na rozumienie drugiego członu w terminie digital humanities - w obu przytoczonych fragmentach „humanistyka” w odniesieniu do obszaru nauk humanistycznych jest pojmowana dosyć szeroko. Burdick, Drucker, Lunenfeld, Presner oraz Schnapp w swojej definicji nie piszą o bezpośrednim powiązaniu digital humanities z humanistyką - można uznać, że założenie takiego związku zostało przyjęte implicite, niemniej w samej definicji mówi się jedynie o tym, że HC dotyczy badań naukowych, w których wykorzystywane są nowoczesne technologie. Może to prowadzić do błędnych wniosków - np. w obszarze nauk ścisłych cyfrowe instrumentarium badawcze jest wykorzystywane od dawna, jednak nie sposób określić tych badań mianem digital humanties.

W drugim cytowanym fragmencie humanistyka cyfrowa odnosi się nie tylko do badań związanych z tradycyjnie rozumianym obszarem problemowym humanistyki, ale również do dziedziny nauk społecznych oraz do domeny sztuki. Takie ujęcie znacznie rozszerza rozumienie terminu $\mathrm{HC}$ oraz również może prowadzić do niewłaściwych wniosków.

\subsection{Definicja Matthew Kirschenbauma}

Drugą, najliczniej cytowaną publikacją, dotyczącą definiowania pojęcia digital humanities jest wspominany wyżej artykuł Matthew Kirschenbauma What Is Digital Humanities and What's It Doing in English Departments?. Opublikowany pierwotnie w 150 numerze czasopisma ADE Bulletin w 2010 r., tekst był kilkukrotnie przedrukowywany (m.in. w Debates in the Digital Humanities oraz Defining Digital Humanities: A Reader) oraz doczekał się 179 cytowań. Poza przywołaniem definicji innych badaczy oraz namysłem nad dziedziną jako taką, Kirschenbaum wysuwa własną propozycję:

Whatever else it might be then, the digital humanities today is about a scholarship (and a pedagogy) that is publicly visible in ways to which we are generally unaccustomed, a scholarship and pedagogy that are bound up with infrastructure in ways that are deeper and more explicit than we are generally accustomed to, a scholarship and pedagogy that are collaborative and depend on networks of people and that live an active 24/7 life online (Kirschenbaum, 2010, 60).

Choć ta wypowiedź nie jest definicją w ścisłym znaczeniu, to badacz ukazuje w niej własny sposób rozumienia humanistyki cyfrowej, co ma szczególne znaczenie ze względu na szeroki oddźwięk wywołany przez publikację. W zacytowanym fragmencie można wyróżnić trzy podstawowe płaszczyzny - przedmiotową, relacyjną oraz jakościową.

Pierwsza z nich dotyczy tego, co należy uznać za główny obiekt w wypowiedzi Kirschenbauma. Są to „a scholarship and a pedagogy”, które można przetłumaczyć jako „studia i sposoby przekazywania wiedzy" (przekład na podstawie Oxford Dictionary oraz Nowego Słownika Fundacji Kościuszkowskiej). Badacz powtarza je konsekwentnie w tym zestawieniu, przez co można rozumieć, że odnoszą się także do czegoś bardziej ogólnego, czyli nauki, a co za tym idzie - humanistyce cyfrowej zostaje przyznany status osobnej dyscypliny. Nie oznacza to jednak, że scholarship można przetłumaczyć tu bezpośrednio na dyscypline - takie odczytanie wynika z celowości zastosowania tego terminu przez autora.

Płaszczyzna relacyjna odnosi się do grona obiorców, którym dla autora What Is Digital Humanities and What's It doing in English Departments? jest społeczność naukowa, do której zaliczają się również osoby nie prowadzące profesjonalnie badań, a „jedynie” zainteresowani nauką. Odbiorcy nauki są nieprzyzwyczajeni do nowych form komunikacji, 
sposobów, w jakie humanistyka cyfrowa staje się widoczna dla większej publiczności choć nie jest to wyrażone wprost, można przypuszczać, że Kirschenbaum miał na myśli m.in. blogi naukowe i Twittera - oraz że wiąże się ona z infrastrukturą (którą w tym kontekście można rozumieć również jako technologię) bardziej wszechstronnie i wnikliwie, niż wynikałoby to ze stereotypu badacza-humanisty, którego większość pracy polega na studiowaniu tekstu w odosobnieniu. Na tej płaszczyźnie uwidacznia się również związek innego typu - studia i sposoby przekazywania wiedzy są zależne od grup osób często korzystających z Internetu oraz aktywnych w mediach społecznościowych, domyślnie: społeczności humanistów cyfrowych.

Sfera jakościowa obejmuje cechy przypisywane humanistyce cyfrowej przez Kirschenbauma; nawet jeśli nie wszystkie zostały wyrażone wprost, można je określić na podstawie analizy dwóch poprzednich płaszczyzn. Kluczową właściwością jest niezależność - badacz mówiąc o digital humanities, przyznaje dyscyplinie pozycję samodzielnej nauki. Następna ważna cecha to nowatorskość, odkrywczość na tyle duża, by zaskakiwać odbiorców; wiąże się to również z wychodzeniem poza schematy. Cały opisywany aspekt połączony jest również ze wspominaną widocznością dla audytorium nie zaznajomionego głębiej z humanistyką cyfrową oraz powiązanie z technologią. Kolejną cechą jest otwartość na współpracę oraz pewne uzależnienie od Internetu - cyfrowi humaniści często pracują nad projektami wspólnie, ale w rozproszeniu, za pośrednictwem sieci.

Kirschenbaum w swojej „definicji” buduje obraz humanistyki cyfrowej jako innowacyjnej dyscypliny, w której stosowane są niestandardowe rozwiązania oraz w której szczególny nacisk kładziony jest na aspekt społecznościowy - rozumiany jako współpraca, praca zespołowa oraz tworzenie społeczności cyfrowych humanistów, komunikujących się ze sobą za pośrednictwem nowych mediów.

\subsection{Definicja N. Katherine Hayles}

Trzecią pod względem popularności publikacją zawierającą definicję pojęcia digital humanities jest artykuł N. Katherine Hayles How We Think: Transforming Power and Digital Technologies, który ukazał się w wydanej w 2012 r. książce Understanding Digital Humanities i według bazy danych wyszukiwarki Google Scholar był cytowany 96 razy. Badaczka przygląda się w nim następstwom praktyk stosowanych w humanistyce cyfrowej i niektórym ważnym dla niej kwestiom, takim jak skala w kontekście badań ilościowych oraz procedury close reading, możliwości wypracowywania teorii czy współpraca. Zależy jej na możliwie szerokim rozumieniu terminu „humanistyka cyfrowa”:

I posit the digital humanities as a diverse field of practices associated with computational techniques and reaching beyond print in its modes of enquiry, research, publication, and dissemination. In this sense, the digital humanities includes text encoding and analysis, digital editions of print works, historical research that re-creates classical architecture in virtual reality formats such as Rome Reborn and The Theater of Pompey, archival and geospatial sites, and since there is a vibrant conversation between scholarly and creative work in this field, electronic literature and digital art that draws on or remediates humanities traditions (Hayles, 2012, 45).

Hayles proponuje definicję zakresową, podzieloną na dwie warstwy - ogólną i szczegółową, z których każda zawiera element wyliczenia. Przeciwnie niż u Kirschenbauma, nie da się tutaj wyróżnić płaszczyzny relacyjnej i jakościowej; w sferze rzeczowej humanistyka 
cyfrowa jest nazwana „diverse field of practices”, co można przetłumaczyć jako „zróżnicowana dziedzina praktyk”. Nacisk nie został położony na samoistność dyscypliny jako takiej, ale na jej aspekt funkcjonalny - po określeniu generalnym następuje doprecyzowanie stosowanych technik („computational techniques”).

W warstwie ogólnej autorka artykułu poza określeniem rzeczowym i powiązaniem dziedziny ze stosowaniem metod obliczeniowych wyszczególnia domeny, w których humanistyka cyfrowa wykracza poza możliwości druku. Należą do nich sposoby: formułowania pytań badawczych, prowadzenia badań, publikowania oraz udostępniania prac. Określenie tożsamości dziedziny zatem dokonuje się tutaj poprzez ustanowienie pewnej opozycji (alternatywy) w stosunku do „tradycyjnej” humanistyki związanej z medium druku; są to zarazem założenia metodologiczne, które nie dotyczą konkretnych postulatów, ale w planie ogólnym sugerują nowoczesność i otwartość.

W warstwie szczegółowej N. Katherine Hayles wymienia, co jej zdaniem zawiera się w humanistyce cyfrowej: kodowanie tekstu i jego analiza, cyfrowe edycje dzieł wydanych wcześniej w druku, badania historyczne odtwarzające klasyczną architekturę w rzeczywistości wirtualnej, archiwalne badania geoprzestrzenne, literatura elektroniczna oraz sztuka cyfrowa czerpiąca z tradycji nauk humanistycznych. Mimo deklaracji dotyczącej chęci włączenia możliwie szerokiego spektrum zjawisk, z dzisiejszej perspektywy zakres praktyk wskazanych przez badaczkę może wydawać się raczej skromny, jednak w momencie ukazania się tekstu był zapewne dosyć nowatorski i odzwierciedlał rozpiętość istotnych ówcześnie tematów dla dziedziny.

Pojawia się tutaj również aspekt networkingu - zwrócona została uwaga na korzyści wynikające z połączenia pracy naukowej i kreatywnej („since there is a vibrant conversation between scholarly and creative work in this field"). Ten wymiar nie jest szczególnie eksponowany, jednak już samo uwzględnienie go w definicji jest znaczące i świadczy o uznaniu za integralny element dyscypliny.

Hayles proponuje definicję, która ma być możliwie inkluzywna, choć paradoksalnie niektóre jej elementy wydają się ograniczać tę otwartość. Niemniej jednak sformułowana przez badaczkę propozycja tworzy spójną całość, która po pewnym uaktualnieniu dalej mogłaby służyć do szerokiego opisu humanistyki cyfrowej.

\subsection{Definicja Digital Humanities Quarterly}

Redaktorzy Digital Humanities Quarterly, najstarszego czasopisma specjalistycznego z dziedziny humanistyki cyfrowej, zadeklarowali w artykule otwierającym pierwszy numer, że odraczają odpowiedź na pytanie „Czym jest humanistyka cyfrowa?”, ponieważ z czasem ramy dyscypliny zostaną nakreślone przez tematykę publikacji ukazujących się na łamach DHQ (Flanders et al., 2007). W zamian postanowili zapytać jak można kształtować humanistykę cyfrową, a dobór tekstów ukazujących się w Digital Humanities Quarterly sugeruje, że szukanie odpowiedzi na to pytanie dalej stanowi ich myśl przewodnią.

Na stronie internetowej periodyku Digital Humanities Quarterly widnieje jednak definicja pojęcia digital humanities, co stoi w sprzeczności z oświadczeniem Julii Flanders, Wendella Pieza i Melissy Terras, ale przybliża problematykę zagadnień poruszanych przez publikowane artykuły. Mając na uwadze fakt, że jest to propozycja uznanego czasopisma, można przyznać jej status normatywny, ponadto jest to jedna z niewielu definicji dziedziny, które można uznać za klasyczne (w rozumieniu systematyki definicji): 
Digital humanities is a diverse and still emerging field that encompasses the practice of humanities research in and through information technology, and the exploration of how the humanities may evolve through their engagement with technology, media, and computational methods (Flanders et al., 2007).

W tym ujęciu można wyróżnić dwa istotne elementy, typowe dla definicji klasycznej: gatunek i różnicę gatunkową. W pierwszej części cytowanego fragmentu - odnoszącej się do gatunku - humanistyka cyfrowa została nazwana zróżnicowaną i ciągle rozwijającą się dziedziną, co określa jej położenie względem innych nauk - Digital Humanities Quarterly uznaje ją za osobną dyscyplinę. Cechy zróżnicowana i ciagle rozwijająca się oddają charakter dziedziny, która nie wypracowała jeszcze własnej metodologii ani nawet nie została do końca określona i wciąż znajduje się w fazie intensywnych zmian. Takie przedstawienie humanistyki cyfrowej mogłoby ją deprecjonować, w rzeczywistości jednak działa na jej korzyść - w ramach młodej dyscypliny można dokonać więcej, przyczyniając się przy tym do kształtowania jej zakresu.

Druga część definicji doprecyzowuje różnice gatunkową, która obejmuje zarówno praktyki badań humanistycznych wykorzystujące technologie informacyjne, jak i badania nad tym, w jaki sposób humanistyka może rozwijać się poprzez wykorzystanie technologii, mediów i metod obliczeniowych. Pierwszy człon tego fragmentu jest dosyć ogólny - nie zostały wymienione konkretne narzędzia ani sposoby ich użycia, chodzi po prostu o zastosowanie narzędzi informatycznych, co pozwala na określenie mianem humanistyki cyfrowej szerokiego spektrum projektów. Drugi człon natomiast tworzy przestrzeń dla metarefleksji o humanistyce - w jaki sposób ją rozwijać przy pomocy nowoczesnych instrumentów.

Taki sposób definiowania osłabia podział na (tradycyjna) humanistykę i humanistyke cyfrowa, zmienia perspektywę widzenia tej pierwszej - być może w przyszłości wszystkie badania humanistyczne będą prowadzone przy pomocy metod wykorzystywanych w humanistyce cyfrowej - oraz osadza tę drugą w kontekście szeroko rozumianej tradycji humanistycznej.

\subsection{Podsumowanie}

Omawiane definicje są dosyć różnorodne - każda z nich inaczej określa humanistykę cyfrową i inny jej aspekt stawia w centrum zainteresowania. Niemniej niektóre właściwości się powtarzają, co umożliwia wskazanie kluczowych cech i ustalenie bazowej definicji humanistyki cyfrowej - a przynajmniej podstawowego sposobu jej pojmowania. Płaszczyzna porównawcza została przedstawiona w tabeli 1.

W tabeli zostały przytoczone cechy humanistyki cyfrowej wymieniane przez każdą z definicji; są uszeregowane według częstotliwości występowania. Poszczególne pozycje mogły być sformułowane w nieco inny sposób, zależnie od definicji, ale na potrzeby tabeli nazewnictwo zostało ujednolicone. Znak + oznacza uwzględnienie danej cechy w definicji.

Jedynym elementem, który pojawia się we wszystkich definicjach, są powiązania z technologią. W propozycjach N. Katherine Halyes oraz Digital_Humanities zostało wyjaśnione, co należy przez nie rozumieć - autorzy piszą o computational techniques (lub computationally engaged research), text encoding oraz wykorzystaniu rzeczywistości wirtualnej. Definicja z Digital Humanities Quarterly również wspomina o computational methods, jednak odnosi się to do rozwijania humanistyki w ogóle; w kontekście humanistyki cyfrowej występuje sformułowanie information technology. Włączenie tej cechy do wszystkich przytoczonych 
prób wyjaśnienia czym jest humanistyka cyfrowa pokazuje, jak duże ma ona znaczenie i że jest konstytutywną częścią składową rozumienia pojęcia digital humanities.

Tabela 1. Porównanie występowania kluczowych cech humanistyki cyfrowej w jej definicjach w literaturze anglojęzycznej

\begin{tabular}{|c|c|c|c|c|}
\hline Cecha & $\begin{array}{l}\text { Digital_Hu- } \\
\text { manities }\end{array}$ & $\begin{array}{l}\text { Kirschen- } \\
\text { baum }\end{array}$ & $\begin{array}{l}\text { N. Katherine } \\
\text { Hayles }\end{array}$ & $\begin{array}{l}\text { Digital Huma- } \\
\text { nities Quarterly }\end{array}$ \\
\hline Powiązania z technologią & + & + & + & + \\
\hline Status dziedziny & & + & + & + \\
\hline Nowatorstwo & + & + & + & \\
\hline Współpraca/Networking & + & + & + & \\
\hline Praktyki badawcze & + & & + & + \\
\hline Sposoby prowadzenia studiów & + & + & & \\
\hline Sposoby przekazywania wiedzy & + & + & & \\
\hline Działalność publikacyjna & + & & + & \\
\hline $\begin{array}{l}\text { Wykraczanie poza możliwości } \\
\text { druku }\end{array}$ & + & & + & \\
\hline Niezależność & & + & & \\
\hline $\begin{array}{l}\text { Otwarcie na innych odbiorców } \\
\text { niż naukowcy }\end{array}$ & & + & & \\
\hline Uzależnienie od Internetu & & + & & \\
\hline $\begin{array}{l}\text { Opozycja do tradycyjnej huma- } \\
\text { nistyki }\end{array}$ & & & + & \\
\hline Ciągły rozwój dyscypliny & & & & + \\
\hline Metarefleksja & & & & + \\
\hline $\begin{array}{l}\text { Osadzenie humanistyki cyfrowej } \\
\text { w ogólnym kontekście humani- } \\
\text { styki }\end{array}$ & & & & + \\
\hline
\end{tabular}

Do najczęściej pojawiających się cech należy status dziedziny, który odnosi się do tego, czy autor lub autorzy danej definicji przyznają humanistyce cyfrowej samodzielny status ontologiczny jako dyscyplinie. Kluczowe dla tej pozycji pojęcie field pojawia się we wszystkich propozycjach, nie we wszystkich jednak w pozytywnym kontekście - redaktorzy Digital_Humanities nie opierają na nim swojego rozumienia humanistyki cyfrowej, o czym wspominałam w interpretacji. Mimo tego oparcie trzech innych definicji na koncepcie dziedziny jest wystarczająco znaczące - samodzielny status ontologiczny wiąże się z większym prestiżem oraz możliwością funkcjonowania jak pozostałe nauki.

Następnym, równie często pojawiającym się określeniem jest nowatorstwo, nieobecne jedynie w propozycji czasopisma Digital Humanities Quarterly. Ta cecha nie musi wiązać się z odkrywczością samych badań - jest obecna raczej w sferze metodologii i podejścia badawczego; ze względu na stosowane narzędzia łączy się z technologią, ale nie dotyczy jej w ścisłym sensie, jest czymś ponad nią. Może odwoływać się do samego konceptu 
interdyscyplinarności lub korzystania z instrumentów, o których wcześniej nie myślano, że mogą mieć zastosowanie w humanistyce.

Współpraca/networking to cecha, która także pojawiła się w trzech spośród czterech przytoczonych definicji. Odnosi się zarówno do współpracy międzyinstytucjonalnej (jak w propozycji z Digital_Humanities), współpracy naukowców (jak u Kirschenbauma), jak i do współpracy branży naukowej i kreatywnej (jak u N. Katherine Hayles). Wskazuje to na charakter samej dziedziny - projekty realizowane w jej ramach opierają się na podziale kompetencji oraz nierzadko tzw. pracy w chmurze; można to uznać za jeden z kluczowych elementów dystynktywnych humanistyki cyfrowej. Trzeba równocześnie pamiętać, że zespołowość badań, networking i komunikacja badaczy za pomocą technologii sieciowych są cechami charakterystycznymi dla całej tzw. Nauki 2.0, a więc są to własności, które łączą HC z Nauką 2.0, odróżniając ją równocześnie od tradycyjnie uprawianej humanistyki.

Ostatnim określeniem, jakie pojawia się w kontekście humanistyki cyfrowej w trzech definicjach równocześnie, są praktyki badawcze, przez które należy rozumieć sposoby działania lub procedury dotyczące prowadzenia badań. Digital_Humanities opiera rozumienie humanistyki cyfrowej na tym pojęciu; wprawdzie N. Katherine Hayles oraz Digital Humanities Quarterly nie stawiają tego terminu w centrum, ale wciąż czynią z niego ważny element swoich propozycji.

Do cech, które pojawiają się w co najmniej dwóch definicjach, należą: sposoby prowadzenia studiów, sposoby przekazywania wiedzy, działalność publikacyjna oraz wykraczanie poza możliwości druku. Można uznać je za istotne, ale nie kluczowe - fundamentalne dla rozumienia humanistyki cyfrowej są określenia pojawiające się w większości źródeł, w tym przypadku w co najmniej trzech tekstach. Cechy lub aspekty występujące tylko w jednej definicji można odebrać jako wariacje jednostkowe, które nie mają jednak zasadniczego znaczenia w szerszym kontekście.

Z tabeli oraz powyższej analizy wynika, że najwięcej określeń które można uznać za najważniejsze zawiera definicja skonstruowana przez N. Katherine Hayles. Nie musi to oznaczać, że jest najlepsza, niemniej sposób rozumienia autorki charakteryzuje pewna wszechstronność, którą warto podkreślić.

Znamienne jest, że wszystkie opisywane cechy odnoszą się do członu „digital” - żadna z definicji nie odnosi się wprost do tego, czym jest humanistyka. W większości przypadków przyjmowane interpretacje pierwszego członu opisują humanistykę jako pole badań wykorzystujące dotychczas druk lub pismo drukowane; jedynie N. Katherine Hayles odnosi się także do sztuki i architektury. Humanistyka w „cyfrowym kontekście” oznaczałaby więc badania zwyczajowo wiązane z literaturą i innymi dziedzinami bazującymi na medium słowa pisanego lub drukowanego przeniesione do komputerowego (cyfrowego) środowiska. Nie zmienia to jednak kluczowych cech humanistyki cyfrowej przyjmowanych najszerzej w literaturze anglojęzycznej, którymi są: powiązania z technologią, status dziedziny, nowatorstwo oraz współpraca/networking.

\section{Definicje humanistyki cyfrowej w literaturze polskiej}

Kwestia definicji humanistyki cyfrowej w polskiej literaturze naukowej przedstawia podobny stopień skomplikowania jak w literaturze anglojęzycznej. Polscy naukowcy mierzą 
się z przeniesieniem pojęcia digital humanities na rodzimy grunt od $2012 \mathrm{r}$ - - pierwszej krajowej konferencji poświęconej problematyce humanistyki cyfrowej „Zwrot cyfrowy w humanistyce" (Bomba \& Radomski, 2013). Nie oznacza to, że wcześniej nie były prowadzone w Polsce projekty, które można by zakwalifikować w ten sposób, czego przykładem jest choćby Narodowy Korpus Języka Polskiego (NKJP, 2008), nad którym rozpoczęto prace w 2008 r. Długą już historię mają w Polsce w szczególności badania nad tzw. inżynierią lingwistyczną (zob. Mykowiecka, 2006), niemniej konferencja z 2012 r. sprawiła, że zaakceptowano humanistykę cyfrową jako osobny nurt badań oraz zwrócono uwagę na możliwości, jakie nowoczesne technologie oferują naukom humanistycznym. To wydarzenie można uznać za swoisty punkt zwrotny dla rozwoju HC w Polsce - od tego momentu możemy mówić o świadomych badaniach nad nią, prowadzonych na gruncie rodzimych instytucji, o czym świadczy operowanie nazwą HC zarówno w nazwach podejmowanych projektów badawczych, jak i w nazewnictwie tworzonych jednostek badawczych.

W artykułach powstających w polskim środowisku naukowym daje się zauważyć pewna niechęć do formułowania definicji - wielu badaczy próbuje odpowiedzieć na pytanie czym jest humanistyka cyfrowa, ale większość z nich skupia się na zakreśleniu jej ram, często w możliwie najszerszy sposób, i rzadko kiedy pojawia się konkluzja zawierająca konkretne sformułowanie problemu. Zdarzają się również sytuacje, w których badacz wręcz odmawia sformułowania definicji, np. Andrzej Radomski w artykule Humanistyka cyfrowa w praktyce - analiza $i$ wizualizacja obrazów napisał otwarcie:

(...) chciałbym zaznaczyć, że nie będę tutaj definiował pojęcia humanistyki cyfrowej. Nie jest to wynik jakiegoś «lenistwa intelektualnego». Po prostu badacze unikają (jak na razie) takiej procedury - ze względu na rozległość pola badawczego oraz ciągle zmieniające się metody i narzędzia. W tym wypadku to praktyka zakreśla sposób rozumienia i uprawiania humanistyki cyfrowej (Radomski, 2015, 6).

Takie ujęcie sprawy wywołuje wrażenie jakby zdefiniowanie humanistyki cyfrowej nie było w ogóle możliwe. Co więcej, na stronach internetowych polskich instytucji zajmujących się HC zazwyczaj nie ma informacji czym jest humanistyka cyfrowa - tak jest np. w przypadku konsorcjum DARIAH-PL (2015), CHC IBL PAN (2017), Centrum Humanistyki Cyfrowej Instytutu Badań Literackich PAN (CHC IBL PAN, 2017) czy nawet Katolickiego Uniwersytetu Lubelskiego, który w ramach swojej oferty edukacyjnej od roku akademickiego 2016/2017 proponuje kierunek studiów drugiego stopnia Humanistyka Cyfrowa (KUL, 2016).

Problem braku definicji humanistyki cyfrowej w polskim dyskursie naukowym został poruszony w 2016 r. w trzech artykułach: wspominanym Co to jest humanistyka cyfrowa? Pole semantyczne pojęcia (zarys) Marii Przastek-Samokowej, Nowa «respublica litteraria»? Humanistyka cyfrowa jako metaorientacja wspótczesnych badań humanistycznych Ewy Solskiej oraz w Humanistyka cyfrowa a socjologia cyfrowa. Nowy paradygmat badań naukowych Magdaleny Szpunar. Ostatnia z wymienionych badaczek do wyżej przytoczonych słów Andrzeja Radomskiego odnosi się wprost:

\footnotetext{
Nie do końca można się zgodzić z Radomskim, który twierdzi, że owo definiowanie utrudniają ciągle zmieniające się narzędzia. Rzeczywiście zgodnie z hipotezą Ogburna warstwa kulturowa nie nadąża za zmianami dokonującymi się w warstwie technologicznej, ale zaznaczyć wyraźnie należy, że metody i narzędzia wcale nie zmieniają się w zawrotnym tempie. Ważniejszą sprawą jest tutaj brak rozumienia i umiejętności analizowania otrzymanych danych (Szpunar, 2016, 358).
}

Szpunar pisze również o tym, że dalsza rezygnacja z wysiłków określenia humanistyki cyfrowej „skazuje ją na utrwalające się traktowanie jej w kategoriach fanaberii cyfrowych 
apologetów” (Szpunar, 2016, 358). Podobnego zdania jest Ewa Solska, według której „w Polsce nie istnieje humanistyka cyfrowa jako programowe przedsięwzięcie" (Solska, 2016, 107). Zdaniem badaczki powinna istnieć debata dotycząca teorii, metodologii i kwestii instytucjonalnych. Obie te wypowiedzi świadczą o tym, jak ważne jest zdefiniowanie terminu „humanistyka cyfrowa” i że brak jasno określonych granic jego zakresu już prowadzi do negatywnych konsekwencji.

Wydawać by się mogło, że ogólna sytuacja nie odbiega tak bardzo od tej, która ma miejsce w świecie literatury anglojęzycznej, niemniej jednak zachodzi kilka istotnych różnic, nawet jeśli podobne wrażenie sprawia chaos związany z brakiem porozumienia między badaczami. Pierwsza z tych różnic dotyczy faktycznego istnienia definicji - w literaturze anglojęzycznej jest ich bardzo dużo, wystarczy chociażby przypomnieć przywoływaną już stronę http://whatisdigitalhumanities.com; w przypadku literatury polskiej należy mówić przede wszystkim o „próbach definicji”, nie o definicjach. Następnie w przypadku literatury angielskiej możliwe jest określenie stopnia oddziaływania definicji i przyjęcie wymiernych wyznaczników tego wpływu; w odniesieniu do literatury polskiej jest to bardzo trudne, ponieważ większość artykułów nie jest indeksowana w bazach podających liczbę cytowań. Trzecią, bardziej ulotną różnicą, która jednak wciąż ma istotne znaczenie, jest „podejście normatywne" - naukowcy publikujący w języku angielskim nie obawiają się konkretyzowania swoich poglądów, podczas gdy polscy badacze, jak wspominałam, sprawiają wrażenie uprzedzonych do tworzenia precyzyjnych sformułowań.

\subsection{Metodologia}

Opisane wyżej różnice między podejściem obecnym w literaturze angielskojęzycznej i polskiej obrazują problemy wiążące się z przyjęciem metodologii służącej do zbadania polskich definicji. Podstawowa trudność wiąże się z kwestią wyodrębnienia materiału badawczego tylko w nielicznych przypadkach za podstawową jednostkę można uznać skonkretyzowaną definicję. W związku z tym zastosowałam metodę podsumowania i przeglądu - sposoby definiowania humanistyki cyfrowej w polskich artykułach zostaną omówione pokrótce, ze wskazaniem najważniejszych cech przypisywanych analizowanemu terminowi przez autora danego tekstu.

Próba badawcza, obejmująca siedem tekstów naukowych (oraz jeden artykuł, który zawiera próbę podsumowania stanowisk polskich badaczy) została pozyskana przez wyszukiwanie proste w bazach CEEOL oraz BazHum, jak również w wyszukiwarce Google, na podstawie terminu „humanistyka cyfrowa”. Następnie w wyniku selekcji teksty zostały ograniczone do tych, w których autor podejmując problematykę humanistyki cyfrowej, stara się zaproponować własną definicję lub przedstawia swoje rozumienie tego terminu, co pozwoliło wykluczyć artykuły zawierające jedynie tłumaczenia definicji. Jest to dosyć istotny element procedury selekcyjnej, ponieważ polscy badacze często cytują wypowiedzi innych naukowców lub po prostu przekładają definicje z języka angielskiego, co sprawia, że nie można uznać ich za autorskie sformułowania. Podsumowania zostały uszeregowane chronologicznie względem roku ukazania się publikacji; jeśli kilka tekstów zostało wydanych w tym samym roku i nie było możliwe ustalenie, który z nich został opublikowany jako pierwszy, zastosowano porządek alfabetyczny według nazwisk badaczy. 


\subsection{Radostaw Bomba, Narzędzia cyfrowe jako wyznacznik nowego paradyg- matu badań humanistycznych}

Tak jak sugeruje tytuł, tekst Radosława Bomby jest poświęcony narzędziom cyfrowym i ich roli we współczesnej humanistyce. Opisana została w nim również humanistyka cyfrowa badacz przedstawił ją w dosyć szeroki sposób, nazywając zarazem „nowym paradygmatem badań”, „szczególną perspektywą badawczą na gruncie współczesnej humanistyki” (Bomba, 2013, 57) oraz „nową dyscypliną” (Bomba, 2013, 69). Użycie tylko tych trzech określeń pokazuje, że według R. Bomby granice $\mathrm{HC}$ są nieostre na tyle, by jednoznaczne określenie jej statusu ontologicznego było dosyć trudne lub wręcz niemożliwe. Takie podejście staje się jednak bardziej zrozumiałe w kontekście kwestii instytucjonalizacji. Mimo tego, że jej korzenie sięgają m.in. digitalizacji przeprowadzanej przez różnego rodzaju instytucje, humanistyka cyfrowa jest

zjawiskiem, które daleko wykracza poza tradycyjne instytucje naukowe, czyli uniwersytety, szkoły, biblioteki, archiwa i muzea (Bomba, 2013, 68),

a jej przyswojenie

wymaga przemyślenia instytucjonalnych ram funkcjonowania humanistyki (Bomba, 2013, 70).

HC wyrasta ponad instytucjonalne ramy i nie może być „tylko” dyscypliną lub nowy podejściem do badań; stając się „czymś więcej”, traci ostrość pozwalającą na zdefiniowanie jej istoty.

Do kluczowych cech humanistyki cyfrowej, według tego badacza, należy oparcie na narzędziach cyfrowych, które mogą ewoluować na jej gruncie; szczególną rolę wśród nich odgrywa wizualizacja. Wiąże się to jednocześnie ze stawianiem badaczom pewnych wymagań - muszą mieć odpowiednie kompetencje, pozwalające na wykorzystywanie i tworzenie oprogramowania używanego w badaniach (Bomba, 2013). Innymi aspektami, na które Bomba zwraca uwagę są: popularność modelu autorstwa zbiorowego, korzystanie z praktyk nawiązujących do norm otwartej nauki, takich jak udostępnianie zasobów i danych w Internecie, dopuszczenie użytkowników do oddolnej produkcji oraz możliwość rejestrowania zachowań ludzkich na szeroką skalę (Bomba, 2013).

Mimo że autor poruszył w swoim artykule wiele wątków dotyczących omawianej tematyki, kluczowe było skoncentrowanie uwagi tylko na treściach związanych z definiowaniem humanistyki cyfrowej. Tym, co najbardziej zwraca uwage w postawie demonstrowanej przez autora jest niemożność zaproponowania jednoznacznej definicji HC oraz dosyć stanowczy stosunek względem zagadnień instytucjonalnych; pozostałe właściwości przypisywane przez niego $\mathrm{HC}$ nie odbiegają zbytnio od tych, które pojawiały się w artykułach anglojęzycznych.

\subsection{Radostaw Bomba, Andrzej Radomski «Wstęp. Zwrot cyfrowy w humanistyce»}

Andrzej Radomski i Radosław Bomba we Wstępie do pracy zbiorowej Zwrot cyfrowy whumanistyce. Internet / Nowe media / Kultura 2.0, z której pochodzi kilka cytowanych w niniejszej pracy artykułów, nie tylko nakreślają ogólną problematykę tomu, ale i przedstawiają własne rozumienie terminu „humanistyka cyfrowa”. Według tych autorów jest to 
idea połączenia refleksji humanistycznej z nowymi narzędziami cyfrowymi, które wykorzystać można do przetwarzania, wizualizowania, prezentowania i popularyzowania wyników badań naukowych (Bomba \& Radomski, 2013, 7).

W kontekście charakteryzowania HC używają oni również określenia „nurt”, co ma swoje konsekwencje, które opiszę później.

W przytoczonej definicji kluczową rolę odgrywają trzy komponenty: refleksja humanistyczna, narzędzia cyfrowe oraz popularyzowanie wyników badań. Pierwszy z nich sytuuje $\mathrm{HC}$ w generalnym kontekście humanistyki, wskazując, że humanistyka cyfrowa i humanistyka „tradycyjna” nie są bytami oderwanymi od siebie. Narzędzia cyfrowe to powtarzający się element również definicji anglojęzycznych; w rozumieniu Bomby i Radomskiego stanowią fundament humanistyki cyfrowej. Mimo pewnej oczywistości w tym kontekście, zwraca uwagę położenie nacisku na wizualizację, która jest uważana za kluczową wśród dostępnych instrumentów. Popularyzowanie wyników badań przy użyciu narzędzi cyfrowych kieruje zaś uwagę w stronę odbiorcy, zyskującego w takim ujęciu na znaczeniu; być może nie musi on nawet należeć do społeczności naukowej.

Wszystkie te pojęcia są zogniskowane wokół nurtu - humanistyka cyfrowa nie jest zatem dyscypliną, ale wiązką opisanych wyżej tendencji, co nadaje jej uniwersalny charakter. Unika się w ten sposób zamknięcia w ramach konkretnych instytucji i poniekąd zaprasza badaczy z całego spektrum humanistycznych dziedzin - HC mogłaby być użyteczna dla każdego z nich.

\subsection{Anna Nacher, «Poza cyfrowość w zwrocie cyfrowym - od humanistyki cyfrowej do spekulatywnej komputacji»}

Anna Nacher w swoim artykule porusza szereg problemów związanych z humanistyką cyfrową: jej historią, przekształceniami czy związkami z pokrewnymi dziedzinami; niewiele pisze jednak o HC „samej w sobie”. Zwraca uwagę na brak krytycznego podejścia do tego zjawiska; wśród konsekwencji, które się z tym wiążą, wymienia ryzyko sprowadzenia humanistyki cyfrowej do wykorzystywania multimediów w praktyce akademickiej, wizualizacji danych i modelowania, digitalizacji archiwów, projektów związanych z wykorzystaniem big data oraz zarządzania informacją (Nacher, 2013). Choć wyraźnie zaznacza, że humanistyka cyfrowa to nie tylko te instrumenty, to jednak fakt wymienienia właśnie ich można uznać za pewien najbardziej podstawowy sposób rozumienia humanistyki cyfrowej. Inne zastrzeżenia względem HC to „predylekcja do wyjaśnień monokazualnych (...) oraz fetyszyzacja jednorodności metodologicznej" (Nacher, 2013, 85), jak również spostrzeżenie, że wnioski z badań prowadzonych pod szyldem humanistyki cyfrowej mają często charakter tautologii (Nacher, 2013).

Badaczka ta zauważa jednak, że HC może być postrzegana jako szansa dla humanistyki na podniesienie jej statusu; zdaniem Nacher,

największą wartością humanistyki cyfrowej jest konieczność przemyślenia na nowo ni mniej, ni więcej, tylko istoty refleksji o charakterze humanistycznym (Nacher, 2013, 85).

Wśród opisywanych cech HC znajduje się również wewnętrzna różnorodność.

W podejściu A. Nacher najbardziej widoczny jest sceptycyzm, ale nie ma on ostatecznego charakteru - badaczka wskazuje na możliwość wykorzystania HC do „promocji” 
humanistyki w ogóle. Jej wypowiedź można odczytywać przede wszystkim jako ostrożne przypomnienie, że do żadnego ze zjawisk nie można podchodzić bezkrytycznie - nawet jeśli budzi znaczny entuzjazm wśród naukowców.

\subsection{Maciej Maryl, F5: Odświeżanie filologii}

Maciej Maryl jest badaczem związanym z Instytutem Badań Literackich Polskiej Akademii Nauk, który problematyce definiowania humanistyki cyfrowej poświęcił artykuł wstępny do jednego z numerów Tekstów Drugich. Odnosi się w nim do projektu http://whatisdigitalhumanities.com/ oraz pisze o zwrocie cyfrowym; zasadniczą część jego tekstu stanowią jednak rozważania na temat tego, co należy rozumieć przez $\mathrm{HC}$.

Maryl pisze wprost:

w humanistyce cyfrowej chodzi, jak sądzę, przede wszystkim o sposób uprawiania nauki, a nie o określony zestaw zagadnień badawczych (Maryl, 2014, 12);

stwierdza również, że

[HC] to nie dyscyplina ani kierunek, tylko raczej ruch czy zespół wspólnych wartości, który przyświeca badaczom z różnych dyscyplin humanistycznych (Maryl, 2014, 11).

W artykule została także podjęta próba wskazania głównych założeń humanistyki cyfrowej; jako pierwsze z nich Maryl wymienia narzędzia, które ze względu na aplikacyjny charakter HC

stają się (...) infrastrukturą badawczą wymagającą ciągłych uaktualnień i stałego utrzymywania (Maryl, 2014, 13).

W tym kontekście istotna jest ponadto wizualizacja, którą badacz rozumie jako narzędzie oferujące możliwość analizy i badania zgromadzonych danych oraz jako sposób prezentacji wyników (Maryl, 2014). Dane same w sobie to kolejne z opisywanych założeń:

teksty stają się narzędziami, a informacje w nich zawarte - danymi (Maryl, 2014, 13)

- tak autor artykułu opisuje wkraczanie instrumentów ilościowych do metodologii badań literackich. Następne z analizowanych aspektów to: budowanie interdyscyplinarnych zespołów jako sposób prowadzenia badań, otwarcie na nowe formy komunikacji naukowej, działania prowadzone w duchu otwartej nauki, nadanie badaczowi nowej roli oraz poszerzenie i zmiana roli odbiorców rezultatów badań naukowych (Maryl, 2014).

Chociaż w ujęciu Maryla humanistyka cyfrowa jest uznawana za nowy sposób prowadzenia badań, a nie za osobną naukę, to dzięki takiemu podejściu zyskuje mocne osadzenie w ogólnym dyskursie humanistycznym. Jak pisze Maryl

humanistyka cyfrowa to naukowy styl życia, który staje się udziałem nas wszystkich (Maryl, 2014, 18)

- można to odczytywać jako prognozę sytuacji, w której tożsamość dziedzinowa, zwłaszcza w obrębie humanistyki, ulegnie zatarciu i każdy naukowiec, zamiast określać się jako literaturoznawca, antropolog czy kulturoznawca będzie po prostu cyfrowym humanistą. Cechy HC wymienione przez M. Maryla wynikają z takiej optyki i wszystkie są wzajemnie powiązane. 


\subsection{Barbara Sosińska-Kalata, «Wstęp» do pracy zbiorowej «Nauka o infor- macji w okresie zmian : informatologia $i$ humanistyka cyfrowa»}

W książce Nauka o informacji w okresie zmian: informatologia $i$ humanistyka cyfrowa zostały zebrane artykuły stanowiące pokłosie konferencji o tym samym tytule; ich autorzy jednak zrezygnowali z prób zdefiniowania humanistyki cyfrowej. Swoje podejście zaproponowała tylko Barbara Sosińska-Kalata we Wstępie do omawianej publikacji:

\footnotetext{
W badaniach humanistycznych proces ten [cyfryzowania warsztatu badawczego - przyp. aut.] nabiera przyspieszenia dopiero w ostatnich kilkunastu latach, prowadząc do coraz bardziej dynamicznego kształtowania się dziedziny określanej jako humanistyka cyfrowa, czy też e-humanistyka. Najogólniej mówiąc, humanistyka cyfrowa wykorzystuje narzędzia i metody informatyczne do badania człowieka i jego twórczości w środowisku cyfrowym oraz rozwija humanistyczną refleksję dotyczącą technologii cyfrowych i ich oddziaływania na kulturę i twórczość człowieka (Sosińska-Kalata, 2016, 11).
}

W przytoczonej definicji trzy najważniejsze elementy to uznanie $\mathrm{HC}$ za dziedzinę nauki, zwrócenie uwagi na narzędzia informatyczne oraz wzmianka dotycząca refleksji o charakterze humanistycznym. O ile status $\mathrm{HC}$ jako dziedziny oraz cyfrowe instrumenty badawcze mogą wydawać się oczywiste w kontekście wyżej omawianych artykułów, o tyle „humanistyczna refleksja dotycząca technologii cyfrowych i ich oddziaływania na kulturę i twórczość człowieka" (Sosińska-Kalata, 2016, 11) nie należy do komponentów definicji HC, które pojawiają się szczególnie często. Jest to o tyle istotne, że cytowany „namysł” lokuje humanistykę cyfrową w szerszej tradycji humanistycznej, jak również nadaje jej jako dziedzinie - pewną zdolność do autorefleksji.

\subsection{Ewa Solska, «Nowa respublica litteraria? Humanistyka cyfrowa jako metaorientacja wspótczesnych badań humanistycznych»}

Ewa Solska rozpoczyna swoje rozważania od kwestii tego czym jest humanistyka, osadzając w tym kontekście rozróżnienie na humanistykę cyfrową i humanistykę słowa; swój artykuł poświęca pierwszej z nich. Zdaniem badaczki humanistyka cyfrowa nie jest odrębną dziedziną przedmiotową - do statusu takiej brakuje jej własnej metodologii - ale można ją uznać za „nowy sposób i reguły ich [badań - przyp. JU] uprawiania, którego celem jest adekwatne usytuowanie szeroko pojętych nauk o człowieku w obecnych kontekstach nauki w ogóle" (Solska, 2016, 102). Ze względu na te uwarunkowania,

[HC] pozostaje metonimiczną formułą retoryczno-perswazyjną, za pomocą której postulatorzy dokonują obiektywizacji zdarzenia zwanego zwrotem cyfrowym w humanistyce, sugerując tym samym, że mamy do czynienia z nowym programem dla nauk humanistycznych (Solska, 2016, 108).

- ten komentarz zbliża tekst Solskiej do sceptycznego tonu A. Nacher; można uznać to za przestrogę przed szerokim etykietowaniem różnych projektów mianem humanistyki cyfrowej.

Ewa Solska postuluje określanie HC

w kategoriach metaorientacji jako rozszerzenia pola badań humanistycznych w stronę cyberprzestrzeni i sieci intermedialnych (Solska, 2016, 108).

W artykule pojawia się również odwołanie do instrumentów badawczych - w opinii autorki humanistyka cyfrowa zaspokaja potrzebę narzędzi, dzięki którym można badać 
to, czego poznanie nie było możliwe wcześniej przez brak odpowiednich metod, zwłaszcza ilościowych; do ich grona zalicza metody analizy statystycznej, metody analizy w badaniach filologicznych oraz w game studies, a także wizualizację (Solska, 2016).

Podsumowując, w rozumieniu autorki tekstu Nowa «respublica litteraria»? Humanistyka cyfrowa jako metaorientacja współczesnych badań humanistycznych, kluczowe wyrażenia dotyczące humanistyki cyfrowej to: formuła retoryczno-perswazyjna, metaorientacja i narzędzia. Badaczka w zdecydowany sposób opowiada się przeciw nadawaniu HC osobnego statusu ontologicznego, sytuuje ją jednak w kontekście nauk i refleksji humanistycznej.

\subsection{Magdalena Szpunar, «Humanistyka cyfrowa a socjologia cyfrowa. Nowy paradygmat badań naukowych»}

Magdalena Szpunar w artykule Humanistyka cyfrowa a socjologia cyfrowa. Nowy paradygmat badań naukowych porusza spektrum zagadnień związanych z humanistyką cyfrową pisze m.in. o jej obecnej sytuacji, nawiązuje do zwrotu cyfrowego, analizuje wypowiedzi innych badaczy oraz omawia kwestię socjologii cyfrowej. Nie proponuje własnej definicji HC, choć w tekście sugeruje jak można by ją określić w czasach masowego ucyfrowienia. Sama określa humanistykę cyfrową jako „paradygmat w nauce” (Szpunar, 2016, 356); wśród jej cech wskazuje

otwartość i gotowość do dzielenia się wiedzą, a także nieustanne uczenie się - także od innych, niekoniecznie profesjonalistów i specjalistów w danej dziedzinie (Szpunar, 2016, 364).

Pojawia się więc tutaj otwarcie społeczności naukowców na osoby spoza świata nauki, co ma dosyć doniosłe znaczenie - oznacza odejście od elitaryzmu. Autorka wspomina również o deinstytucjonalizacji i pracy zespołowej, zaznacza też jednak, że „humanistyka cyfrowa nie jest tożsama z otwartą nauką” (Szpunar, 2016, 365), co pozwala przyjąć pewne ramy ograniczające.

\subsection{Podsumowanie}

Obraz, jaki wyłania się z przeanalizowanych tekstów, jest dosyć niejednorodny; można wyróżnić tylko kilka słów-kluczy, które pojawiają się jednocześnie w kilku artykułach. Tabelaryczne zestawienie cech $\mathrm{HC}$ wyodrębnianych przez polskich autorów, jak to uczyniono w przypadku literatury anglojęzycznej, byłoby więc mało użyteczne ze względu na duże rozproszenie używanych określeń, jednak możliwe jest stworzenie pewnego podsumowania stanowisk prezentowanych przez polskich badaczy.

W każdym z omawianych tekstów pojawia się nawiązanie do narzędzi humanistyki cyfrowej. Niektórzy autorzy szczegółowo je dyskutują, inni jedynie o nich wspominają, niemniej dla wszystkich są one istotne. Należy je interpretować jako kluczowy komponent humanistyki cyfrowej - w rozumieniu polskich naukowców konstytuują one jej byt. Najczęściej wymienianym narzędziem jest wizualizacja - została wyszczególniona aż w czterech artykułach.

Większość badaczy jest zgodna, że humanistyka cyfrowa nie jest dyscypliną naukową takie stwierdzenie, nawet jeśli wyrażone nie wprost, pojawia się $\mathrm{w}$ czterech $\mathrm{z}$ siedmiu omawianych tekstów: Radosław Bomba i Andrzej Radomski piszą o nurcie, Ewa Solska 
o metaorientacji, Magdalena Szpunar o paradygmacie w nauce, a Maciej Maryl określa HC przede wszystkim jako sposób uprawiania nauki. Pojęcie paradygmatu pojawia się także w artykule Bomby, który jednak nazywa HC także dyscyplina, podobnie jak Barbara Sosińska-Kalata, która używa terminu dziedzina; jedynie Anna Nacher nie odnosi się do tej kwestii. Taka perspektywa przekłada się na mocniejsze usytuowanie humanistyki cyfrowej na gruncie "tradycyjnej” humanistyki - niezależnie od przyjętego stanowiska, wszyscy cytowani naukowcy żywią przekonanie o współzależności obu „humanistyk”.

Następne punkty styczne to otwarcie społeczności naukowców na nową publiczność, nawiązywanie do norm otwartej nauki oraz praca zespołowa - piszą o tym Radosław Bomba, Maciej Maryl oraz Magdalena Szpunar. Pierwsze z wymienionych zagadnień jest związane z przemianą modelu komunikacji naukowej - naukowcy, korzystając z blogów oraz innych platform w obrębie mediów społecznościowych mają możliwość dotarcia do osób spoza świata nauki, które mogą być zainteresowane tematyką prac danego badacza. Korzystanie z otwartych licencji jest z kolei pewną tendencją, która zaczyna być zauważalna w naukach humanistycznych, a praca zespołowa to nierzadko konsekwencja prowadzenia interdyscyplinarnych projektów, do zrealizowania których potrzebne są kompetencje z różnych dziedzin.

Dwie pozostałe kwestie, występujące w więcej niż jednym artykule, to deinstytucjonalizacja oraz refleksja humanistyczna. Problematyka wyjścia poza sztywne instytucjonalne ramy pojawia się w tekstach Radosława Bomby oraz Magdaleny Szpunar. O refleksji humanistycznej piszą z kolei Radosław Bomba i Andrzej Radomski we wspólnym tekście oraz Barbara Sosińska-Kalata; w obu przypadkach jest to namysł nad połączeniem humanistyki i nowych technologii oraz efektami takiego zespolenia.

Trudno byłoby określić przeanalizowane wyżej cechy jako fundamentalne dla polskiego rozumienia humanistyki cyfrowej, przede wszystkim ze względu na fakt, że rozpatrywane były nie definicje, a całe artykuły, których autorzy zastanawiali się nad naturą omawianego zjawiska. Niemniej, celem tej części pracy nie było poszukiwanie definicji wspólnej, którą można byłoby uznać za pewną normę, a jedynie przegląd stanowisk autorów podejmujących rozważania o naturze humanistyki cyfrowej.

\section{Definiowanie humanistyki cyfrowej w piśmiennictwie anglojęzycznym i polskim}

Między sposobami definiowania humanistyki cyfrowej w piśmiennictwie anglojęzycznym i polskim można zauważyć kilka istotnych różnic, o czym wspominałam przy okazji pisania o ogólnej sytuacji normatywnej terminu „humanistyka cyfrowa” w pracach polskich naukowców. Przeprowadzona analiza rodzimych tekstów umożliwia jednak nakreślenie bardziej szczegółowej sytuacji porównawczej.

Najczęściej powtarzany w tekstach polskich naukowców element związany z humanistyką cyfrową - narzędzia cyfrowe - jest zbieżny z najpopularniejszą cechą z artykułów anglojęzycznych, którą są powiązania z technologią. Oba sformułowania można uznać za odnoszące się do tego samego zjawiska, którym jest wprowadzenie instrumentów cyfrowych do humanistyki. Drugą z cech wspólnych stanowi praca zespołowa, istotna zarówno dla naukowców publikujących po polsku, jak i po angielsku. Pozostałe właściwości, które pojawiły się zarówno w literaturze polskiej, jak i w angielskiej - otwarcie społeczności naukowców na 
nową publiczność oraz refleksja humanistyczna - są mniej znaczące jako punkty wspólne, ponieważ w literaturze anglojęzycznej wspomniano o nich tylko jednokrotnie.

Większość anglojęzycznych autorów jest zgodna co do przyznania HC statusu dziedziny, natomiast polscy naukowcy w większości mają całkowicie odmienne zdanie - dla nich humanistyka cyfrowa nie jest dyscypliną. Chociaż proponują różne jej interpretacje (m.in. jako paradygmat czy metaorientacja), niezgoda na autonomiczny status ontologiczny wyznacza elementarną różnicę między sposobem pojmowania HC demonstrowanym w piśmiennictwie polskim i tym, który dominuje w piśmiennictwie anglojęzycznym. Inną rozbieżność stanowi fakt, że w polskim piśmiennictwie humanistyka cyfrowa jest osadzona w tradycji humanistycznej; w artykułach anglojęzycznych taka koncepcja pojawia się tylko u jednego z najczęściej cytowanych autorów, a kolejny sytuuje humanistykę cyfrową w opozycji do tradycyjnej. Pozostałe dwie cechy HC, najczęściej pojawiające się w polskich tekstach naukowych, odwoływanie się do standardów otwartej nauki oraz deinstytucjonalizacja, nie pojawiły się w piśmiennictwie anglojęzycznym w ogóle.

Porównanie sposobów definiowania humanistyki cyfrowej przez autorów rodzimych i anglojęzycznych uwidacznia kluczowe podobieństwo i kluczową różnicę. Podobieństwo leży w oparciu definicji na pojęciu narzędzi cyfrowych, które siłą rzeczy wiążą humanistykę z technologią i które są niezbędne do uprawiania humanistyki cyfrowej. Różnica widoczna jest przede wszystkim w podejściu do statusu HC jako dziedziny/dyscypliny: polscy naukowcy w większości nie uznają HC za takową, podczas gdy anglojęzyczni zgadzają się na jej odrębny status ontologiczny. Warto zauważyć również, że polscy autorzy o wiele częściej odwołują się do definicji humanistyki samej w sobie, co może wpływać na szerszy ogląd sytuacji.

\section{Bibliografia}

Berry, D. M. (2012). Introduction: Understanding the Digital Humanities. In: D. M. Berry (eds.), Understanding Digital Humanities. Basingstoke: Palgrave Macmilan UK, 1-20.

Bomba, R. (2013). Narzędzia cyfrowe jako wyznacznik nowego paradygmatu badań humanistycznych. W: R. Bomba, A. Radomski (red.), Zwrot cyfrowy w humanistyce. Internet / Nowe Media / Kultura 2.0. Lublin: E-Naukowiec, 57-72.

Bomba, R.; Radomski, A. (2013). Wstęp. Zwrot cyfrowy w humanistyce. W: R. Bomba, \& A. Radomski (red.), Zwrot cyfrowy w humanistyce. Internet / Nowe Media / Kultura 2.0. Lublin: E-naukowiec, 7-9.

Burdick, A.; Drucker, J.; Lunenfeld, P.; Presner, T.; Schnapp, J., eds. (2012). Digital_Humanities. Cambridge, Massachusetts: The MIT Press.

CHC IBL PAN (2017). Centrum Humanistyki Cyfrowej IBL PAN [online]. Centrum Humanistyki Cyfrowej IBL PAN, [15.03.2017], http://chc.ibl.waw.pl/pl/

DARIAH-PL ( (2015). Konsorcjum Dariah-PL [online] Konsorcjum Dariah-PL, [15.03.2017], http:// dariah.pl

DH Manifesto 2.0. (2009). A Digital Humanities Manifesto [online], A Digital Humanities Manifesto, UCLA [3.03.2017], http://manifesto.humanities.ucla.edu/2009/05/29/the-digital-humanities-manifesto-20/

Digital Humanities Quarterly. About DHQ [online]. Digital Humanities Quarterly, [28.02.2017], http://www.digitalhumanities.org/dhq/about/about.html

Flanders, J.; Piez, W.; Terras, M. (2007). Welcome to Digital Humanities Quarterly [online]. Digital Humanities Quarterly, March [1.03.2017], http://www.digitalhumanities.org/dhq/ $\mathrm{vol} / 1 / 1 / 000007 / 000007 . h \mathrm{ml}$

Gibbs, F. (2013). Digital Humanities Definitions by Type. In: M. Terras, J. Nyhan, E. Vanhoutte (eds.), Defining Digital Humanities: A reader. Farnham; Burlington: Ashgate, 289-298. 
Hayles, N. K. (2012). How We Think: Transforming Power and Digital Technologies. In: D. M. Berry (ed.), Understanding Digital Humanities. Basingstoke: Palgrave Macmillan UK, 42-66.

Kamiński, Stanisław (1998). Nauka i metoda. Pojęcie nauki i klasyfikacja nauk. Lublin: Towarzystwo Naukowe KUL.

Kirschenbaum, M. G. (2010). What Is Digital Humanities and What's It Doing in English Departments? ADE Bulletin, (150), 55-61.

KUL (2016). Humanistyka cyfrowa [online]. Katolicki Uniwersytet Lubelski. Serwis dla kandydata, [15.03.2017], http://www.kul.pl/humanistyka-cyfrowa,art_65557.html

Maryl, M. (2014). F5: odświeżanie filologii. Teksty Drugie, 2, 9-20.

Mykowiecka, A. (2006). Inżynieria lingwistyczna. Komputerowe przetwarzanie tekstów w języku naturalnym. Warszawa: PJWSTK.

Nacher, A. (2013). Poza cyfrowość w zwrocie cyfrowym - od humanistyki cyfrowej do spekulatywnej komputacji. W: R. A. Bomba Radosław (red.), Zwrot cyfrowy w humanistyce. Internet / Nowe Media / Kultura 2.0. Lublin: E-naukowiec, 83-97.

NKJP (2008). O projekcie NKJP [online]. Narodowy Korpus Języka Polskiego, IPI PAN; IJP PAN; Wydawnictwo Naukowe PWN; Zakład Językoznawstwa Komputerowego i Korpusowego Uı [3.03.2017], http://nkjp.pl/

Przastek-Samokowa, M. (2016). Czym jest humanistyka cyfrowa? Pole semantyczne pojęcia (zarys). Zagadnienia Informacji Naukowej, 54(2), 82-93.

Radomski, A. (2015). Humanistyka cyfrowa w praktyce - analiza i wizualizacja obrazów. Roczniki kulturoznawcze, 6(4), 5-15.

Solska, E. (2016). Nowa „respublica litteraria”? Humanistyka cyfrowa jako metaorientacja współczesnych badań humanistycznych. Roczniki Kulturoznawcze, 7 (1), 99-118.

Sosińska-Kalata, B. (2016). Wstęp. W: B. Sosińska-Kalata (red.), Nauka o informacji w okresie zmian: informatologia i humanistyka cyfrowa. Warszawa: Wydaw. SBP, 9-13.

Svensson, P. (2013). Humanities Computing as Digital Humanities. In: M. Terras, J. Nyhan, \& E. Vanhoutte (Redaktorzy), Defining Digital Humanities: A reader. Farnham; Burlington: Ashgate, 159-186.

Svensson, P. (2012). The digital humanities as a humanities project. Arts and Humanities in Higher Education, 11(1-2), 42-60.

Szpunar, M. (2016). Humanistyka cyfrowa a socjologia cyfrowa. Nowy paradygmat badań naukowych. Zarzadzanie w Kulturze, 17(4), 355-369.

Terras, M.; Nyhan, J.; Vanhoutte, E. (2013a). Introduction. In: M. Terras, J. Nyhan, \& E. Vanhoutte (eds.), Defining Digital Humanities: A reader. Farnham; Burlington: Ashgate, 1-10.

Terras, M.; Nyhan, J.; Vanhoutte, E. (2013b). Selected Definintions from the Day of Digital Humanities: 2009-2012. In: M. Terras, J. Nyhan, \& E. Vanhoutte (eds.), Defining Digital Humanities: A Reader. Farnham; Burlington: Ashgate, 278-288.

Vanhoutte, E. (2013). The Gates of Hell: History and Definintion of Digital | Humanities | Computing. In: T. Melissa, N. Julianne, \& V. Edward (eds.), Defining Digital Humanities: A Reader. Farnham; Burlington: Ashgate, 119-156.

\title{
Digital Humanities: Problems in Defining the Concept
}

\author{
Abstract \\ Purpose/Thesis: This article attempts to indicate a set of the most common features of digital hu- \\ manities and to determine what the term $\mathrm{DH}$ really means.
}


Approach/Methods: The author examines English and Polish scientific articles discussing the definitions of digital humanities and juxtaposes them.

Results and conclusions: The result is negative as it is not possible to create one set of digital humanities features, nevertheless it is possible to find some most often occurring features.

Originality/Value: This article provides the first systematic analysis and compilation of Polish and English-language definitions of the digital humanities.

\section{Keywords}

Analysis. Definitions. Digtal. Humanities. Digital humanities.

JOANNA UCIŃSKA ukończyła studia magisterskie na kierunku Informacja naukowa i bibliotekoznawstwo, specjalizacja: Architektura Informacji i Wiedzy, który studiowała w ramach studiów w Kolegium Międzywydziałowych Indywidualnych Studiów Humanistycznych i Spotecznych na Uniwersytecie Warszawskim. Do zainteresowań badawczych autorki należa: humanistyka cyfrowa, wykorzystanie nowych technologii w naukach humanistycznych, użytkownicy informacji, kompetencje cyfrowe (ang. data literacy), inżynieria wiedzy oraz funkcjonowanie nowych technologii w kontekście społecznym.

Kontakt $z$ autorka:

joanna.ucinska@student.uw.edu.pl 